\title{
OCENA WIEDZY KOBIET CIEZŻARNYCH NA TEMAT PORODU ORAZ METOD ŁAGODZENIA BÓLU PORODOWEGO
}

\section{ASSESSMENT OF PREGNANT WOMEN'S KNOWLEDGE ABOUT LABOUR AND METHODS OF PAIN RELIEF DURING LABOUR}

\author{
Mariola Gałązka ${ }^{a}$, Dominika Gałaś ${ }^{b}$, Maria Trębacz $^{c}$, Klaudia Sieńko-Hans $^{d}$ \\ Wydział Nauk o Zdrowiu, Uniwersytet Jagielloński \\ ${ }^{a}$ https://orcid.org/0000-0002-5918-8808 \\ ${ }^{\mathrm{b}} \mathrm{https}: / /$ orcid.org/0000-0002-3180-0962 \\ ${ }^{c}$ https://orcid.org/0000-0003-1659-8388 \\ ${ }^{\mathrm{d}}$ https://orcid.org/0000-0002-8751-8747
}

DOI: https://doi.org/10.20883/pielpol.2019.36

\section{STRESZCZENIE}

Wstęp. Dobre przygotowanie kobiety do porodu wymaga uzyskania przez nią rzetelnej wiedzy pochodzącej od specjalistów. Kobieta ciężarna posiadająca wiedzę na temat mechanizmu porodu oraz jego przebiegu ma większe szanse na poród naturalny przebiegający bez niechcianych komplikacji.

Cel. Celem niniejszej pracy jest ocena poziomu wiedzy kobiet ciężarnych na temat podstawowych zagadnień związanych z porodem fizjologicznym.

Materiał i metody. Badaniem objęto 421 kobiet ciężarnych. Do przeprowadzenia badań wykorzystano metodę sondażu diagnostycznego. Narzędziem badawczym był kwestionariusz ankiety. Wyniki. Największa grupa ciężarnych ma dostateczny poziom wiedzy na temat porodu (40,6\%). Wystarczający, czyli dość wysoki i bardzo wysoki poziom wiedzy na temat porodu, ma łącznie tylko 14\% ankietowanych. Średnia ilość uzyskanych przez respondentki punktów wyniosła 12,1 punktów.

Wnioski. Poziom wiedzy kobiet ciężarnych na temat podstawowych zagadnień dotyczących porodu jest niezadowalający. Nie wykazano zależności pomiędzy uczestnictwem w zajęciach w Szkole Rodzenia a poziomem wiedzy ciężarnych.

SŁOWA KLUCZOWE: kobieta, ciąża, poród, wiedza.

\section{Wprowadzenie}

Poród to bardzo ważny moment zarówno w życiu matki, dziecka, jak i całej rodziny. Kluczowe znaczenie ma w nim przygotowanie rodzącej do tego wydarzenia [1]. Pozwala ono na lepszą współpracę z zespołem terapeutycznym oraz zrozumienie całego procesu, jakim jest poród. Przygotowanie to odbywa się w Szkołach Rodzenia, ale także w trakcie każdej wizyty u ginekologa czy położnej. Głównymi zadaniami i celem Szkół Rodzenia są działania psychoprofilaktyczne, promocja zdrowia, propagowanie zasad higieny w ciąży, podczas

\begin{abstract}
Introduction. Right preparation of a woman for childbirth requires from her to obtain reliable knowledge from specialists. A pregnant woman who has got knowledge of delivery has got a better chance of a natural delivery without unwanted complications. Aim. The purpose of this study is to assess the level of knowledge about natural childbirth which have pregnant women. Material and methods. The study included 421 pregnant women. In the study a diagnostic survey and a questionnaire technique were used.

Results. The largest group of pregnant women has a sufficient level of knowledge about labor (40.6\%). Only $14 \%$ of respondents have a fairly high and very high level of knowledge about childbirth. The average number of points scored by respondents was 12.1 points.

Conclusions. The level of pregnant women's knowledge on the basic issues of labor is unsatisfactory. There was no correlation between the participation in classes at the School of Birth and the level of knowledge of pregnant women.
\end{abstract}

KEYWORDS: woman, pregnancy, childbirth, knowledge.

porodu i połogu, a także przygotowanie partnerów do rodzicielstwa. Dzięki rzetelnej edukacji w zakresie fizjologii porodu i metod łagodzenia bólu istnieje większa szansa na uniknięcie niechcianych komplikacji podczas porodu, a rodząca, która jest dobrze przygotowana do swojej roli, potrafi współpracować z personelem medycznym $[2,3,4,5,6]$.

\section{Cel pracy}

Celem pracy jest ocena poziomu wiedzy kobiet ciężarnych na temat porodu oraz niefarmakologicznych i far- 
makologicznych metod łagodzenia bólu porodowego, a także zbadanie zależności pomiędzy uczestnictwem w zajęciach w Szkole Rodzenia, liczbą przebytych porodów i wykształceniem a poziomem wiedzy na temat porodu.

\section{Materiał i metody}

Badania przeprowadzono w maju 2018 roku wśród kobiet ciężarnych. Udział w badaniu był dobrowolny, a respondentki zostały zapewnione o anonimowości ankiety. Ostateczną grupę badaną stanowiło 421 ciężarnych. W pracy zastosowano metodę sondażu diagnostycznego z użyciem techniki ankietowej. Kwestionariusz ankiety składał się z części formalno-ewidencyjnej, w której zawarto informacje na temat celowości badania. W kwestionariuszu zawarto metryczkę, która zbierała dane dotyczące wieku, miejsca zamieszkania oraz wykształcenia osób respondowanych. W dalszej części kwestionariusza zamieszczono pytania dotyczące przedmiotu badań. Ogółem w kwestionariuszu zawarto 22 pytania otwarte i zamknięte. Ponadto do wybranych pytań zamieszczono w sumie 9 pytań uściślających. Pytania dostarczyły informacji na temat przygotowania pacjentek do porodu, a także sprawdzały wiedzę ciężarnych. Ankietowanym przyznawano punkty za poprawne odpowiedzi. Za udzielenie wszystkich poprawnych odpowiedzi można było zdobyć w sumie 26 punktów. Na potrzeby badania zmienną poziom wiedzy na temat porodu podzielono na: bardzo mały poziom wiedzy (0-6 pkt.), mały poziom wiedzy (7-11pkt.), umiarkowany, dostateczny poziom wiedzy (12-16 pkt.), wystarczający, wysoki poziom wiedzy (17-21pkt.), bardzo wysoki poziom wiedzy (22-26 pkt.). Natomiast uczestnictwo w Szkole Rodzenia (TAK) uznano w przypadku stwierdzenia przez badaną, że uczęszczała lub jest w trakcie kursu.

W badaniu związki analizowane były za pomocą testów analitycznych. Oznaczono typy zmiennych. Sprawdzono, czy zmienne w badaniu mają rozkład zgodny z rozkładem normalnym. Do weryfikacji tego użyto testu Shapiro-Wilka. Do analizy związku pomiędzy zmiennymi jakościowymi użyto test chi-kwadrat, natomiast zmienne porządkowe z ilościowymi analizowano za pomocą korelacji rang Spearmana. Istotność statystyczną przyjęto na poziomie $\alpha=0,05$. Analizę wykonano w programie Statistica. Grupę badaną stanowiło 421 kobiet w okresie okołoporodowym. Ciężarne były zróżnicowane pod względem wieku, wykształcenia, miejsca zamieszkania i liczby przebytych porodów. Największą grupe stanowiły kobiety z wyższym wykształceniem w wieku 25-29 lat, mieszkające w dużych miastach, które rodziły raz.
Tabela 1. Charakterystyka grupy badanej Table 1. Characteristic of the study group

\begin{tabular}{|c|c|c|}
\hline & $\begin{array}{l}\text { Liczba } \\
\text { respondentek/ } \\
\text { Number } \\
\text { of respondents }\end{array}$ & {$[\%]$} \\
\hline \multicolumn{3}{|l|}{ WYKSZTAŁCENIE/EDUCATION } \\
\hline Wyższe/Higher & 198 & 47 \\
\hline Średnie/Secondary & 165 & 39,2 \\
\hline Zawodowe/Formal Professional & 36 & 8,6 \\
\hline Podstawowe/Basic & 22 & 5,2 \\
\hline \multicolumn{3}{|l|}{ WIEK/AGE } \\
\hline$<20$ & 25 & 5,9 \\
\hline $21-24$ & 126 & 29,9 \\
\hline $25-29$ & 170 & 40,4 \\
\hline $30-34$ & 79 & 18,8 \\
\hline$>35$ & 21 & 5 \\
\hline \multicolumn{3}{|l|}{ MIEJSCE ZAMIESZKANIA/PLACE OFRESIDENCE } \\
\hline Wieś/Country & 125 & 29,7 \\
\hline $\begin{array}{l}\text { Miasto poniżej } 50 \text { tys. mieszkańców/town with } \\
<50 \text { th. residents }\end{array}$ & 66 & 15,7 \\
\hline $\begin{array}{l}\text { Miasto od } 50 \text { do } 200 \text { tys. mieszkańców/town } \\
\text { with 50-200 th. residents }\end{array}$ & 82 & 19,5 \\
\hline $\begin{array}{l}\text { Miasto powyżej } 200 \text { tys. mieszkańców/town } \\
>200 \text { th. residents }\end{array}$ & 148 & 35,2 \\
\hline \multicolumn{3}{|l|}{ LICZBA PORODÓW/NUMBER OF CHILDBIRTHS } \\
\hline 0 & 140 & 33,3 \\
\hline 1 & 196 & 46,6 \\
\hline 2 & 62 & 14,7 \\
\hline 3 i więcej/3 and more & 23 & 5,5 \\
\hline
\end{tabular}

Źródło: opracowanie własne

Source: author's own analysis

\section{Wyniki}

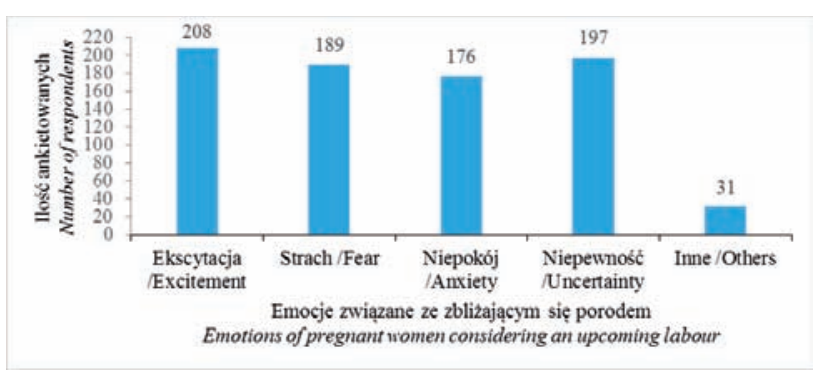

Rycina 1. Emocje związane ze zbliżającym się porodem Figure 1. Emotions of pregnant women considering an upcoming labour Źródło: opracowanie własne

Source: author's own analysis

Wśród ankietowanych prawie połowa - 49,4\% - kobiet na myśl o porodzie czuje ekscytację, lecz podobny procent - 46,8\% - odczuwa jednocześnie niepewność. Strach deklaruje 44,9\%, a z kolei niepokój 41,8\%. Inne emocje wypunktowane przez ciężarne to radość, spokój, ale również przerażenie. 15 respondentek przyznaje się do chęci rozwiązania ciąży sposobem cięcia cesar- 
skiego z powodu strachu lub traumy po wcześniejszym trudnym porodzie naturalnym, co stanowi 3,56\% badanych. Zdecydowana większość kobiet $(75,1 \%)$ ocenia swoje nastawienie do porodu jako pozytywne. Nastawienie negatywne i obojętne deklaruje kolejno 11,8\% i $13,1 \%$ ankietowanych kobiet.

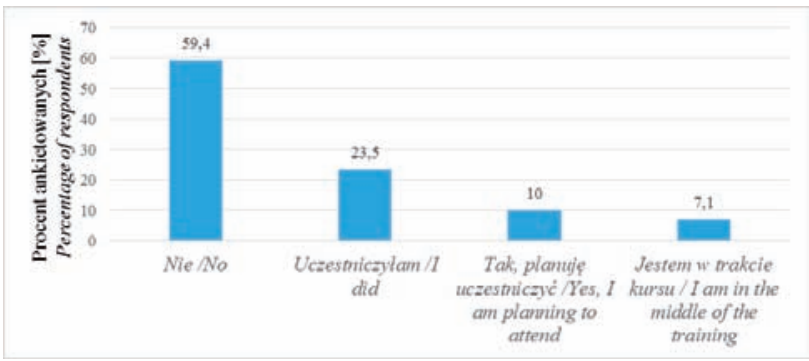

Rycina 2. Uczestnictwo w zajęciach w Szkole Rodzenia Figure 2. Attendence to the classes of the School of Childbirth

Źródło: opracowanie własne

Source: author's own analysis

Uczestnictwo lub chęć uczestnictwa w zajęciach w Szkole Rodzenia deklaruje łącznie 40,6 \% ciężarnych. Pozostała część ankietowanych nie zamierza brać udziału w takim przygotowaniu do porodu. Jako główny powód ankietowane wskazują brak czasu, korzystanie $z$ innych form edukacji, zbyt duże koszty finansowe. Aż $19,2 \%$ ankietowanych wskazało, że nie czuje potrzeby uczestniczenia w zajęciach w Szkole Rodzenia.

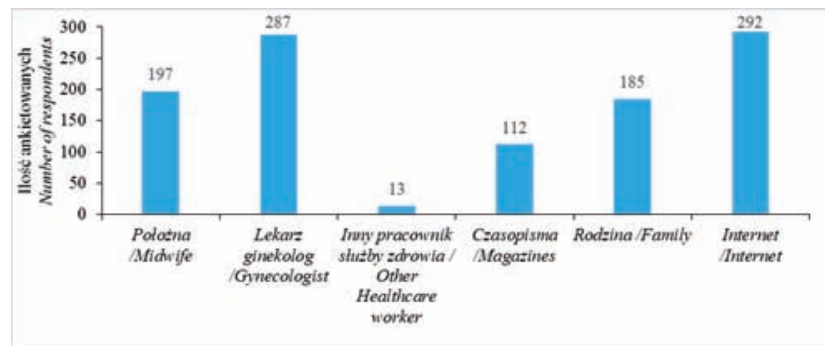

Rycina 3. Źródła wiedzy ankietowanych kobiet na temat porodu Figure 3. Sources of knowledge for pregnant women about childbirth Źródło: opracowanie własne

Source: author's own analysis

Najwięcej respondentek (69,4\%) wskazuje Internet jako główne źródło informacji na temat porodu. Poprzez odpowiedź na pytanie uściślające ankietowane wśród stron internetowych, z których korzystają, wymieniają w większości blogi parentingowe, fora internetowe oraz grupy na portalach społecznościowych. Równie wiele spośród zapytanych kobiet korzysta z wiedzy uzyskanej od swojego lekarza ginekologa.

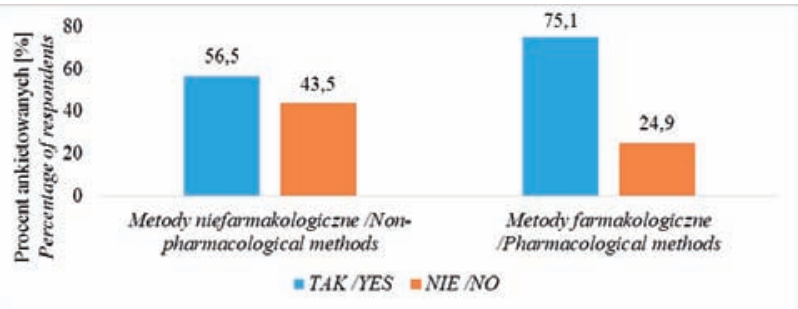

Rycina 4. Znajomość farmakologicznych i niefarmakologicznych metod łagodzenia bólu

Figure 4. Knowledge of the pharmacological and non-pharmacological methods of pain relief

Źródło: opracowanie własne

Source: author's own analysis

Powyższy wykres obrazuje deklarowaną znajomość farmakologicznych i niefarmakologicznych metod łagodzenia bólu porodowego. Po zweryfikowaniu odpowiedzi okazuje się, że odpowiednio 48,2\% i 65,8\% ankietowanych potrafi poprawnie wymienić niefarmakologiczne i farmakologiczne metody łagodzenia bólu porodowego, a więc deklarowana wiedza nie jest rzeczywista z wiedzą posiadaną przez ankietowane.

Zdecydowana większość ankietowanych (64\%) nie wie, jakie dokumenty zabrać ze sobą do szpitala. Ankietowane zostały zapytane, kiedy natychmiast zgłosić się do szpitala. Zdecydowana większość respondentek dobrze odpowiedziała na to pytanie. Według 91,4\% kobiet do szpitala należy zgłosić się natychmiast w przypadku wystąpienia regularnej akcji skurczowej co 5 minut, 90,7\% odpowiada, iż należy to zrobić obserwując masywne krwawienie z dróg rodnych, a z kolei 88,1\% uważa, że przy odpływaniu zielonego płynu owodniowego. Aż 49,9\% ankietowanych kobiet uważa, że odpłynięcie czystych wód płodowych jest powodem do natychmiastowego udania się do szpitala. $24,5 \%$ wskazuje, iż pobolewania dołem brzucha są wskazaniem do niezwłocznej wizyty w szpitalu. 8,6\% udałoby się do szpitala w przypadku regularnej akcji skurczowej występującej co 40 minut, a 3,3\% ankietowanych w przypadku nieregularnych skurczów macicy ustępujących po kąpieli.

Poprawne definicje wszystkich czterech okresów porodu wskazało jedynie 114 respondentek (27\%) jednocześnie zdobywając maksymalną liczbę 4 punktów za to pytanie. 104 ciężarne (24,7\%) nie wskazały ani jednej poprawnej definicji okresów porodu.

W ankiecie zawarto pytania, które sprawdzały wiedzę ciężarnych na temat porodu. Pytania dotyczyły farmakologicznych i niefarmakologicznych metod łagodzenia bólu porodowego, czasu trwania i charakterystyki okresów porodu, dokumentów, które należy zabrać do szpitala do porodu, sytuacji, w których na- 
leży udać się pilnie do szpitala. Łącznie każda ciężarna mogła uzyskać z testu 26 punktów. Średnia ilość uzyskanych przez respondentki punktów wyniosła 12,1 pkt. Najwięcej pacjentek uzyskało 10 punktów - były to 42 ankietowane.

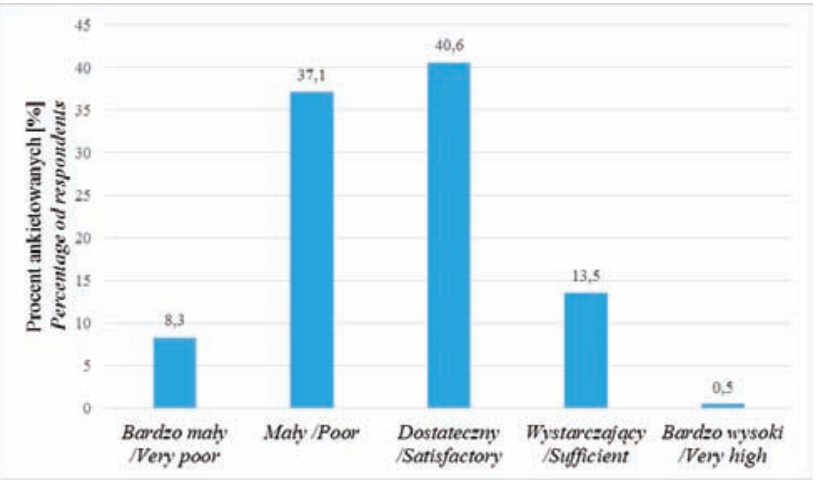

Rycina 5. Poziom wiedzy ankietowanych na temat porodu z podziałem na kategorie

Figure 5. The level of knowledge of respondents about labor with categories

Źródło: opracowanie własne

Source: author's own analysis

Największa grupa ciężarnych ma dostateczny poziom wiedzy na temat porodu (40,6\%). Wystarczający - dość wysoki i bardzo wysoki poziom wiedzy na temat porodu ma łącznie tylko $14 \%$ ankietowanych.

Przeprowadzono analize dwóch zmiennych - porządkowej (liczba przebytych porodów) oraz ilościowej (suma uzyskanych punktów) w celu uzyskania informacji, czy istnieje związek pomiędzy liczbą przebytych porodów a wzrostem wiedzy pacjentek. Ocena korelacji wykazała, że istnieje istotny statystycznie dodatni związek pomiędzy liczbą przebytych porodów a poziomem wiedzy, ale związek ten bardzo słaby $(r=0,1)$.

Ponadto sprawdzono czy uczestnictwo w zajęciach w Szkole Rodzenia miało wpływ na poziom wiedzy pacjentek o porodzie. Za pomocą testu chi-kwadrat zbadano tę zależność między dwiema cechami jakościowymi. Test nie wykazał istotnej statystycznie zależności $(p=0,07)$.

Zbadano także zależność pomiędzy wykształceniem ankietowanych a ich poziomem wiedzy na temat porodu. Wykazano zależność pomiędzy wykształceniem a poziomem wiedzy ciężarnych ( $p<0,0001$ ). Osoby z wyższym wykształceniem mają większy poziom wiedzy w stosunku do pozostałych osób. Poziom wiedzy mały i bardzo mały ma najwięcej osób z wykształceniem podstawowym. Warto zauważyć, że żadna z ankietowanych z wykształceniem podstawowym nie wykazywała wystarczającego i bardzo wysokiego poziomu wiedzy.
Tabela 2. Rozkład poziomu wiedzy w grupach wykształcenia Table 2. Schedule of knowledge considering gained education

\begin{tabular}{|c|c|c|c|c|c|c|c|}
\hline \multirow{3}{*}{$\begin{array}{l}\text { Wykształcenie } \\
\text { Education }\end{array}$} & \multicolumn{7}{|c|}{$\begin{array}{l}\text { Poziom wiedzy/ } \\
\text { Level of knowledge }\end{array}$} \\
\hline & \multicolumn{2}{|c|}{$\begin{array}{c}\text { Bardzo } \\
\text { mały } \\
\text { i mały/ } \\
\text { Very } \\
\text { poor and } \\
\text { poor }\end{array}$} & \multicolumn{2}{|c|}{$\begin{array}{c}\text { Umiarko- } \\
\text { wany } \\
\text { (dosta- } \\
\text { teczny)/ } \\
\text { Satisfac- } \\
\text { tory }\end{array}$} & \multicolumn{2}{|c|}{$\begin{array}{l}\text { Wystarcza- } \\
\text { jący (dość } \\
\text { wysoki) } \\
\text { i bardzo } \\
\text { wysoki/ } \\
\text { Sufficient } \\
\text { (quite high } \\
\text { and high) }\end{array}$} & \multirow[b]{2}{*}{$P$} \\
\hline & $\mathrm{n}$ & $\%$ & $\mathrm{n}$ & $\%$ & $\mathrm{n}$ & $\%$ & \\
\hline Podstawowe/Basic & 17 & 77 & 5 & 23 & 0 & 0 & \multirow{4}{*}{$p<0,001$} \\
\hline $\begin{array}{l}\text { Zawodowe/Formal } \\
\text { professional }\end{array}$ & 24 & 67 & 11 & 31 & 1 & 3 & \\
\hline Średnie/Secondary & 82 & 50 & 68 & 41 & 15 & 9 & \\
\hline Wyższe/Higher & 68 & 34 & 87 & 44 & 43 & 22 & \\
\hline
\end{tabular}

Źródło: opracowanie własne

Source: author's own analysis

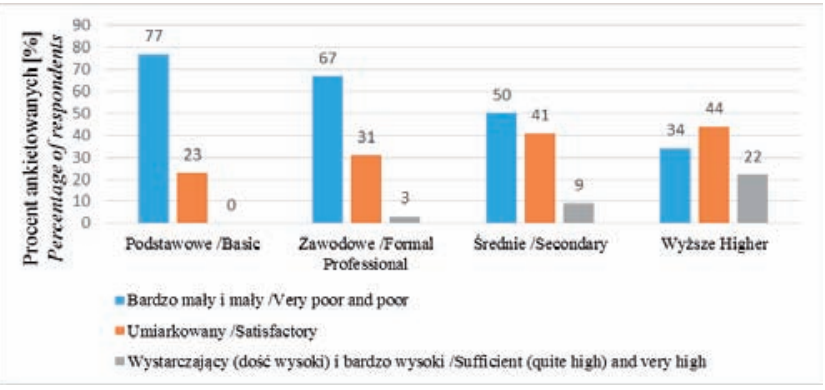

Rycina 6. Rozkład poziomu wiedzy w grupach wykształcenia Figure 6. Schedule of knowledge considering gained education

Źródło: opracowanie własne

Source: author's own analysis

\section{Dyskusja}

Przeprowadzenie porodu naturalnego bez komplikacji wymaga nie tylko odpowiednich kompetencji ze strony personelu, ale także odpowiedniej wiedzy ze strony ciężarnych pacjentek. Znajomość przebiegu poszczególnych okresów porodu oraz możliwego czasu ich trwania nie tylko pozwala na lepszą współpracę pacjentek z personelem, ale przede wszystkim pozwala im samym czuć się bezpieczniej. Jak wynika z przeprowadzonego badania, źródłem wiedzy, do którego najczęściej sięgają ciężarne, jest Internet $(69,4 \%)$. Do podobnych wniosków doszła w swoich badaniach Doroszewska A. i DmochGajzlerska E: Internet był źródłem wiedzy o zdrowiu dla $80 \%$ ankietowanych [4]. W badaniach PuszczałowskiejLizis E. zauważono natomiast, iż pierworódki, które uczęszczały na zajęcia Szkoły Rodzenia, najczęściej korzystały z wiedzy położnych, a ciężarne niekorzystające z edukacji przedporodowej częściej czerpały wiedzę 
z Intenetu, ulotek oraz literatury fachowej [3]. Pozytywny pozostaje fakt, iż w badaniach autorskich lekarz ginekolog jako źródło wiedzy plasuje się na drugim miejscu $(68,2 \%)$. W obecnych czasach dużą uwagę skupia się na przyjmowaniu pozycji wertykalnych w czasie porodu. 52\% ankietowanych w powyższym badaniu nie wie, czym są pozycje wertykalne. W podobnym badaniu z 2014 roku dotyczącym edukacji kobiet ciężarnych $57,14 \%$ badanych osób stwierdziło, że wybór pozycji do porodu jest indywidualną kwestią każdej rodzącej [1]. Jak jednak mogą wybrać pozycję, jeżeli ponad połowa badanych osób nie zdaje sobie sprawy, czym jest pozycja wertykalna? Mimo znacznego deficytu wiedzy wśród kobiet ciężarnych, nie decydują się one na uczestnictwo w zajęciach przygotowujących do porodu. W badaniach własnych odsetek tych kobiet wyniósł 59,4\% ankietowanych. W badaniach Małeckiej A. i Nowaka Z. $87 \%$ ankietowanych nie uczestniczyło w zajęciach przygotowujących do porodu, z czego $30 \%$ „nie czuło potrzeby" uczestnictwa w tychże [5]. W badaniach własnych 19,2 \% odpowiadających wyraziło brak potrzeby uczestnictwa w edukacji przedporodowej. Część zgromadzonej literatury wykazała, że kobiety uczestniczące w zajęciach Szkoły Rodzenia były lepiej przygotowane do ciąży i porodu, a zdobyta wiedza wpłynęła pozytywnie na poprawę ich samopoczucia oraz zwiększyła ich świadomość [3]. W badaniach Kazimierczak i wsp. [2] wykazano brak zależności pomiędzy poziomem wiedzy na temat połogu a uczestnictwem w zajęciach Szkoły Rodzenia. W badaniach własnych także nie zaobserwowano korelacji wynikającej z uczestnictwa w Szkole Rodzenia z ilością uzyskanych punktów. Może to być wynikiem zróżnicowania grupy badawczej pod względem ilości przebytych porodów: pytanie o uczestnictwo w zajęciach przygotowujących do porodu dotyczyło jedynie obecnej ciąży, nie uwzględniało faktu, iż ankietowane mogły uczestniczyć w nich w poprzednich ciążach.

Znajomość metod i środków łagodzących ból porodowy ułatwia wybór najbardziej odpowiedniego dla danej pacjentki. Wybór ten jest również uzależniony od dostępności konkretnej metody w ofercie podmiotu leczniczego. Wśród niefarmakologicznych metod łagodzenia bólu porodowego wyróżnia się psychoprofilaktykę przedporodową, aktywność fizyczną, techniki oddychania i relaksacji, zastosowanie pozycji wertykalnych, masaż, wykorzystanie sprzętów (np. worek sako, piłka), zastosowanie stymulacji nerwowej TENS, imersję wodną. Wśród mniej popularnych metod należy wspomnieć aromaterapię, muzykoterapię, akupunkturę czy hipnozę. Pośród metod farmakologicznych stosuje się leki przeciwbólowe, leki rozkurczające, znieczulenie zewnątrzoponowe a także stosowany wziewnie podtle- nek azotu. Przeprowadzone badanie pokazało, iż większość respondowanych kobiet myliło pojęcia farmakologicznego i niefarmakologicznego łagodzenia bólu. W badaniu Chudobiny i wsp. [6] zauważono, że najbardziej znanymi metodami łagodzenia bólu w czasie porodu są ćwiczenia na piłce, ćwiczenia oddechowe, masaż okolicy lędźwiowo-krzyżowej oraz immersja wodna. Podobne wnioski zawarto w badaniu Król i wsp. [7]: najbardziej znanymi metodami były: prawidłowe oddychanie, masaż, immersja wodna, użycie piłki porodowej oraz środki farmakologiczne. Ponadto w badaniu Majchrzak i wsp. [8] zauważono, że w grupie uczestniczek kursów Szkoły Rodzenia występuje dużo większy odsetek osób znających poszczególne metody łagodzenia bólu porodowego w porównaniu do kobiet, które nie uczestniczyły w zajęciach.

Mimo rosnącej świadomości społeczeństwa, dobrej dostępności do rzetelnych źródeł wiedzy, jakimi są położne, lekarze oraz zajęcia organizowane dla ciężarnych, trudno jest uzyskać wystarczający poziom wiedzy z zakresu tematyki okołoporodowej. Niestety, wiele ciężarnych uważa, że nie potrzebują dodatkowej wiedzy lub Internet jest jej wystarczającym źródłem, a liczne badania wskazują, że uczestnictwo w zajęciach psychoprofilaktyki porodowej ma pozytywny wpływ zarówno na przygotowanie fizyczne, jak i psychiczne kobiety ciężarnej i jej partnera do zbliżającego się porodu.

\section{Wnioski}

1. Przygotowanie teoretyczne kobiet do porodu jest na bardzo niskim poziomie. Średnia ilość uzyskanych punktów przez respondentki wyniosła 12,1 pkt., co nie stanowi nawet połowy możliwych uzyskanych punktów.

2. Istnieje istotny statystycznie dodatni związek pomiędzy liczbą przebytych porodów a poziomem wiedzy, ale związek ten jest bardzo słaby. Uczestnictwo w zajęciach w Szkole Rodzenia nie ma wpływu na poziom wiedzy pacjentek o porodzie.

3. Kobiety z wyższym wykształceniem mają większy poziom wiedzy na temat porodu.

4. Zdecydowana większość kobiet ciężarnych korzysta z niesprawdzonych i nierzetelnych źródeł wiedzy, często niepotwierdzonych naukowo wśród których wymienia się fora internetowe czy grupy dyskusyjne kobiet ciężarnych.

5. Zdecydowana większość ankietowanych oczekując na rozwiązanie czuje pozytywne emocje, ale także niepokój.

6. Kobiety ciężarne w dużej mierze mylą pojęcia niefarmakologicznego i farmakologicznego łagodzenia bólu. 


\section{Piśmiennictwo}

1. Król M, Kaczor P, Grobelny M. Jakie zagadnienia należy poruszyć w edukacji kobiet ciężarnych na temat porodu nieobciążonego patologią? Med Og Nauk Zdr.2014. 20 (3): 245-250.

2. Kazimierczak M, Gebuza G, Gierszewska M. Zaburzenia emocjonalne okresu poporodowego. Probl Pielęg. 2010; 18(4): 503-511.

3. Puszczałowska-Lizis E, Mokrzycka K, Jandziś S. Wpływ edukacji przedporodowej na przebieg ciąży, porodu i wczesne macierzyństwo. Med Og Nauk Zdr., 2016. 4 (22): 264-269.

4. Doroszewska A, Dmoch-Gajzlerska E. Internet jako źródło informacji o ciąży, porodzie, połogu i pielęgnacji dziecka analiza wyników badań. ZdrPub. 2011; 121(2): 129.

5. Małecka A, Nowak Z. Opinia badanych kobiet w ciąży dotycząca ważności uczestnictwa w szkole rodzenia jako formy przygotowania do porodu, Prz Lek. 2014, 71, 8, 473-440.

6. Chudobina A, Woźniewski M, Mraz M. Wpływ szkoły rodzenia na praktyczne wykorzystywanie i skuteczność niefarmakologicznych metod łagodzenia bólu podczas porodu. Fizjoterapia 2012. 20 (3): 21-29.

7. Król M, Kaczor P, Grobelny M. Znajomość metod korzystnie wpływających na przebieg porodu wśród ciężarnych z województwa lubelskiego. Med Og Nauk Zdr.. 2014. 20 (3): 251-255.

8. Majchrzak M. i in. Sposoby łagodzenia bólu porodowego w doświadczeniu położnic. Zdrowie i dobrostan. 2014. 2: 91-99.
9. Rozporządzenie Ministra Zdrowia z dnia 23 września 2010 r. w sprawie standardów postępowania oraz procedur medycznych przy udzielaniu świadczeń zdrowotnych z zakresu opieki okołoporodowej sprawowanej nad kobietą w okresie fizjologicznej ciąży, fizjologicznego porodu, połogu oraz opieki nad noworodkiem (Dz.U.10.187.1259).

10. Kaźmierczak M, Sołdyńska M, Gierszewska M, Gebuza G, Mieczkowska E. Ocena lęku przed porodem u kobiet ciężarnych. Piel. Zdr. Publ.2017. 26(1): 69-75.

11. Smolarek N, Pięt M, Żurawska J, Szpunar R, Pięta B. Alternatywne sposoby łagodzenia bólu porodowego. Pol Prz Nauk Zdr. 2016. 1 (46): 74-80.

Artykuł przyjęty do redakcji: 21.08.2018.

Artykuł przyjęty do publikacji: 03.04.2019.

Źródło finansowania: Praca nie jest finansowana z żadnego źródła. Konflikt interesów: Autorzy deklarują brak konfliktu interesów.

\author{
Adres do korespondencji: \\ Mariola Gałązka \\ Wydział Nauk o Zdrowiu, Uniwersytet Jagielloński \\ ul. Mińska 6 \\ 05-306 Jakubów \\ tel.: 603057001 \\ e-mail: mariola_galazka@icloud.com
}

